\title{
Magnetic properties and potential barrier between crystallites model of $\mathrm{MgGa}_{2-\mathrm{x}} \mathrm{Fe}_{\mathrm{x}} \mathrm{O}_{4}$ ceramics
}

\section{(Propriedades magnéticas e modelo de barreiras de potencial entre cristalitos de cerâmicas de $\left.\mathrm{MgGa}_{2-x} \mathrm{Fe}_{x} \mathrm{O}_{4}\right)$}

\author{
V. A. dos S. Ribeiro", R. M. Rubinger, A. F. Oliveira, C. S. P. Mendonça, M. R. da Silva \\ Instituto de Física e Química, Universidade Federal de Itajubá, Itajubá, MG, Brazil 37500-903 \\ *vanderalkmin@gmail.com,rero@unifei.edu.br, adhimarflavio@unifei.edu.br, sales.claudiney21@gmail.com, \\ mrsilva@unifei.edu.br
}

\begin{abstract}
The aim of this work was to investigate the magnetic properties and the electrical conductivity temperature dependence associated to the potential barrier between the crystallites model. Gallium and magnesium containing spinel ceramic has low magnetic coercivity and high electrical resistivity. $\mathrm{MgGa}_{2-\mathrm{x}} \mathrm{Fe}_{\mathrm{x}} \mathrm{O}_{4}$ samples ( $\left.\mathrm{x}=0.01,0.05,0.15,0.25,0.35\right)$ were prepared by solid-state method and sintered at $800{ }^{\circ} \mathrm{C}$ for $8 \mathrm{~h}$. X-ray diffraction analysis confirmed the formation of a single phase with compact cubic spinel structure. The magnetic measurements show that the saturation magnetization and remanence of all samples increased with increasing iron concentration. The coercive field decreased up to the concentration $\mathrm{x}=0.15$, and above $\mathrm{x}=0.25$ it was observed an increase in the coercive field. Through electrical characterization it was found that the samples presented highly insulating behavior for $\mathrm{x}=0.01$, and further increase in $\mathrm{x}$ above 0.15 gives a semiconductor behavior compatible with the potential barrier between the crystallites model, i.e. fulfills the condition $\mathrm{L} / 2>$ $\mathrm{L}_{\mathrm{D}}$ (crystallite size L in comparison with the Debye length $\mathrm{L}_{\mathrm{D}}$ ), and the conduction is limited by potential barriers between the crystallites. Keywords: spinel, magnetic properties, potential barrier.
\end{abstract}

\section{Resumo}

O objetivo deste trabalho foi investigar as propriedades magnéticas e a dependência da condutividade elétrica com a temperatura associada ao modelo de barreiras de potencial entre os cristalitos. A cerâmica de espinélio de gálio e magnésio possui baixa coercividade magnética e alta resistividade elétrica. As amostras de $\mathrm{MgGa}_{2-x} \mathrm{Fe}_{x} \mathrm{O}_{4}(x=0,01,0,05,0,15,0,25,0,35)$ foram preparadas pelo método de estado sólido e sinterizada a $800^{\circ} \mathrm{C}$ durante $8 \mathrm{~h}$. A análise de difração de raio X confirmou a formação de única fase com estrutura de espinélio cúbico compacto. As medições magnéticas mostraram que a magnetização de saturação e remanescência de todas as amostras aumentaram com a concentração de ferro. O campo coercitivo diminuiu até a concentração $x=0,15$ e acima de $x=0,25$ observou-se um aumento no campo coercivo. Através da caracterização eléctrica verificou-se que as amostras apresentaram comportamento isolante para $x=0,01$ e acima de $x=0,15$ observou-se um comportamento semicondutor compativel com o modelo de barreira de potencial entre cristalitos, ou seja, preenche a condição de $L / 2>L_{D}$ (tamanho de cristalito L em comparação com o comprimento de Debye) e a condução é limitada por barreiras de potencial entre os cristalitos.

Palavras-chave: espinélio, propriedades magnéticas, barreira de potencial.

\section{INTRODUCTION}

In recent years, the study of the spinel $\mathrm{MGa}_{2} \mathrm{O}_{4}(\mathrm{M}=\mathrm{Zn}$, $\mathrm{Mg}$ ) has attracted much attention due to its high electrical resistivity and interesting magnetic properties such as low coercivity, low magnetic losses, low remanence, low saturation magnetization, and low coercive field $[1,2]$. In normal spinel the oxygen ions are positioned in a facecentered cubic closed-packed arrangement with metal ions occupying the interstices. The unitary cell contains 32 oxygen atoms with 96 interstices $\left(32 \mathrm{~B}^{3+}\right.$ octahedral sites and 64 tetrahedrally coordinated $\mathrm{A}^{2+}$ sites) $[3,4]$. The $\mathrm{MgGa}_{2} \mathrm{O}_{4}$ has a partially inverted spinel structure belonging to the space group $\mathrm{Fd} 3 \mathrm{~m}$ with cell parameter $\mathrm{a}=8.2733 \AA[4$, 5]. In the inverted spinel, the $\mathrm{B}^{3+}$ cations occupy tetrahedral sites while $\mathrm{A}^{2+}$ and $\mathrm{B}^{3+}$ cations are distributed randomly on octahedral sites.

The magnetic properties, such as magnetic permeability, coercivity and magnetic losses are strongly correlate to the microstructure, chemical composition, and crystal structure [6-8]. In addition, the electrical properties are mainly controlled when the traps states in the region between the crystallites are present, and the conductivity of material changes due to the capture of free carriers. Polycrystalline materials are made of small crystallites usually joined at their surfaces via grain-boundaries $[9,10]$. Therefore, the conductivity of polycrystalline materials is related to the potential barrier between the crystallites. According to potential barrier between the crystallites model, in a polycrystal, the region between the crystallites presents 
a large number of defects, which act as effective carrier traps $[9,10]$. This model states that, when the trapping states in crystallite region are unoccupied, they create a depletion region in the crystallite and a potential barrier at the interface $[9,10]$. This reduces the number of free carriers available for electrical conduction. In this work, the investigations are extended by studying magnetic properties and the temperature dependent conductivity of these ceramic materials in terms of potential barrier between the crystallites model.

\section{EXPERIMENTAL}

$\mathrm{MgGa}_{2-\mathrm{x}} \mathrm{Fe}_{\mathrm{x}} \mathrm{O}_{4}$ samples with stoichiometry $\mathrm{x}=0.01,0.05$, $0.15,0.25$ and 0.35 were prepared by solid-state method using $\mathrm{MgO}, \mathrm{Ga}_{2} \mathrm{O}_{3}$ and $\mathrm{Fe}_{2} \mathrm{O}_{3}$ (99.9\% purity, Sigma-Aldrich). Initially, the oxides were weighed, taking into account the stoichiometry $\mathrm{x}$ and mixed and ground in an agate mortar for about $1 \mathrm{~h}$. Using a uniaxial press, the samples were compacted up to a pressure of $293 \mathrm{MPa}$ and finally sintered at $800{ }^{\circ} \mathrm{C}$ for $8 \mathrm{~h}$ in ambient atmosphere.

$\mathrm{X}$-ray diffraction analyzes were performed using a diffractometer (URD 65, Seifert \& Com. ID 3000) using $\mathrm{CuK} \alpha$ radiation in the $2 \theta$ range of $10^{\circ}$ to $70^{\circ}$ with a step size of $0.02^{\circ}$ and counting time of $2 \mathrm{~s}$. The identification of the phases was carried out using the PDF2-ICDD database of software High Score Plus. The average crystallite size of the particles was determined by using the Debye-Scherrer formula. Magnetic hysteresis loops $\mathrm{M}(\mathrm{H})$ were measured using a Lakeshore 7404 vibrating sample magnetometer (VSM) in the magnetic field range of $10 \mathrm{kG}$ at room temperature. The magnetization was measured as a function of the temperature using a high temperature attachment from Princeton Applied Research, $151 \mathrm{M}$, from room temperature to $1000{ }^{\circ} \mathrm{C}$. The DC resistivity $(\rho)$ of the samples was measured by two-probe as a function of temperature. Due to high resistivity of ferrite samples, two probe method is useful for ceramics; the measurements were taken in the range of temperature between 300 to $725 \mathrm{~K}$. The real part (Z') and imaginary part (-Z') of the complex impedance of the samples were obtained by the impedance analyzer. The permittivity was calculated from the values of $Z$, obtained by fitting the complex impedance plots and the sample dimensions. The capacitance was measured using Novo Control Technologies, Apha A High Performance Frequency Analyzer, at room temperature and then the dielectric permittivity was calculated within frequency range of $1 \mathrm{~Hz}$ to $40 \mathrm{MHz}$.

\section{RESULTS AND DISCUSSION}

Fig. 1 shows the X-ray diffraction patterns obtained using $\mathrm{CuK} \alpha$ radiation. The diffraction peaks clearly provide evidence for the formation of series of solid solution between $\mathrm{MgGa}_{2} \mathrm{O}_{4}$ (JCPDF 01-072-1520) and $\mathrm{MgFe}_{2} \mathrm{O}_{4}$ (JCPDF 01088-1943). Diffraction patterns of these compounds show the typical diffraction peaks of the same basic structure,

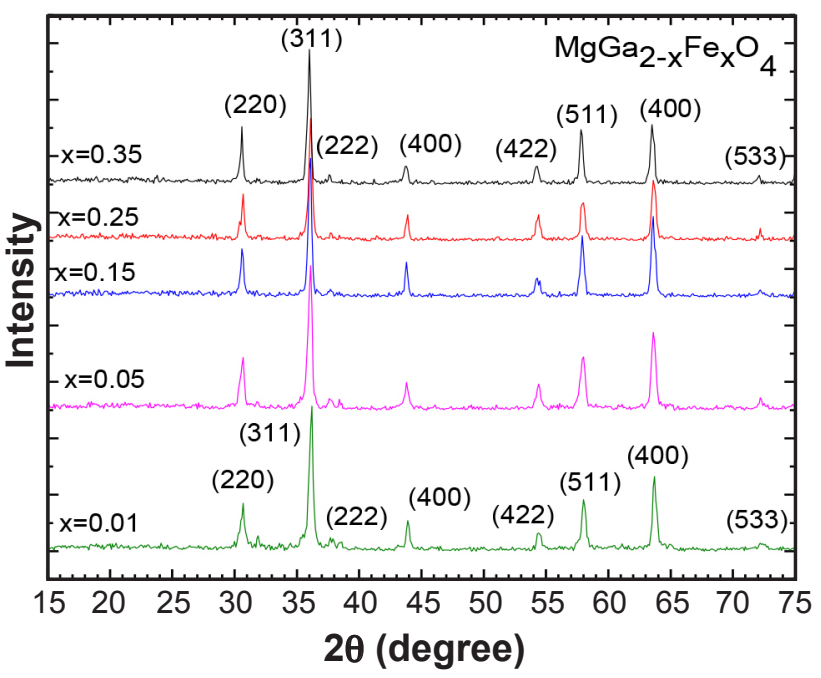

Figure 1: X-ray diffraction patterns of $\mathrm{MgGa}_{2-\mathrm{x}} \mathrm{Fe}_{\mathrm{x}} \mathrm{O}_{4}$ samples. [Figura 1: Difratogramas de raios $\mathrm{X}$ de amostras de $\mathrm{MgGa}{ }_{2-x} \mathrm{Fe}_{x} \mathrm{O}_{4}$.]

as the $\mathrm{MgGa}_{2} \mathrm{O}_{4}-\mathrm{MgFe}_{2} \mathrm{O}_{4}$. It was observed in all iron concentration range the development of a compact singlephase cubic spinel type structure.

Fig. 2 shows magnetic hysteresis loops of $\mathrm{MgGa}_{2-\mathrm{x}} \mathrm{Fe}_{\mathrm{x}} \mathrm{O}_{4}$. It was possible to determine the values of some parameters such as coercive field $\left(\mathrm{H}_{\mathrm{c}}\right)$, remanent magnetization $\left(\mathrm{M}_{\mathrm{r}}\right)$, and saturation magnetization $\left(\mathrm{M}_{\mathrm{s}}\right)$. Through the magnetic hysteresis loops, it can be seen that the samples did not reach the magnetic saturation at low fields, same behavior presented by Ga-substituted $\mathrm{MnFe}_{2} \mathrm{O}_{4}$ [11].

The temperature dependence of the magnetization for all samples of $\mathrm{MgGa}_{2-\mathrm{x}} \mathrm{Fe}_{\mathrm{x}} \mathrm{O}_{4}$ is shown in Fig. 3. It can be seen from this figure that all samples studied have ferromagnetic ordering below Curie temperature $\left(\mathrm{T}_{c}\right)$ while the spontaneous magnetization increases with increasing the $\mathrm{Fe}^{3+}$ concentration (x). It is clear that the magnetization decreased with the increases in temperature, as would be expected from a system with ferromagnetic coupling below $T_{c}$. It is also clear that $T_{c}$ increase with increasing $x$. This

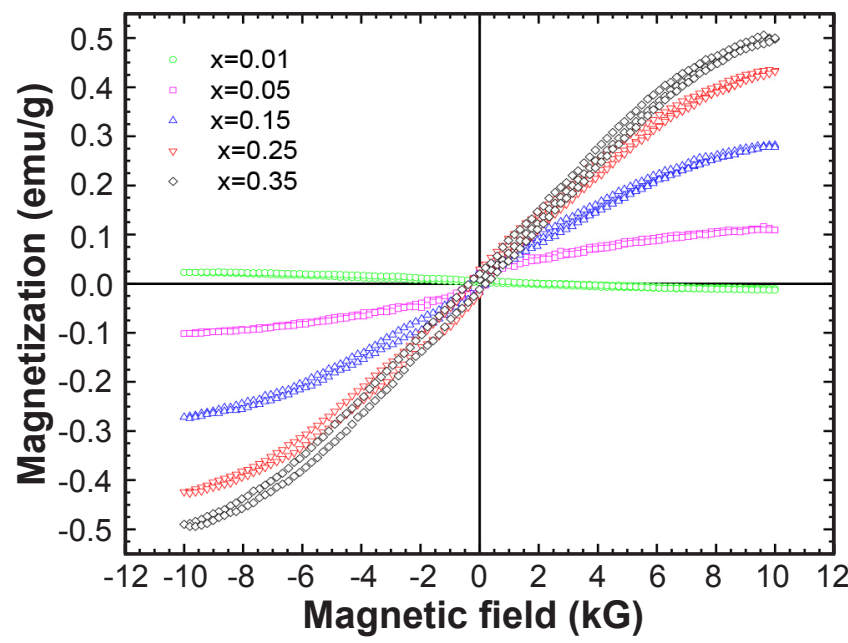

Figure 2: Hysteresis loops for the $\mathrm{MgGa}_{2-\mathrm{x}} \mathrm{Fe}_{\mathrm{x}} \mathrm{O}_{4}$ samples. [Figura 2: Ciclo de histerese para as amostras de $\mathrm{MgGa}{ }_{2-x} \mathrm{Fe}_{x} \mathrm{O}_{4 .]}$ 


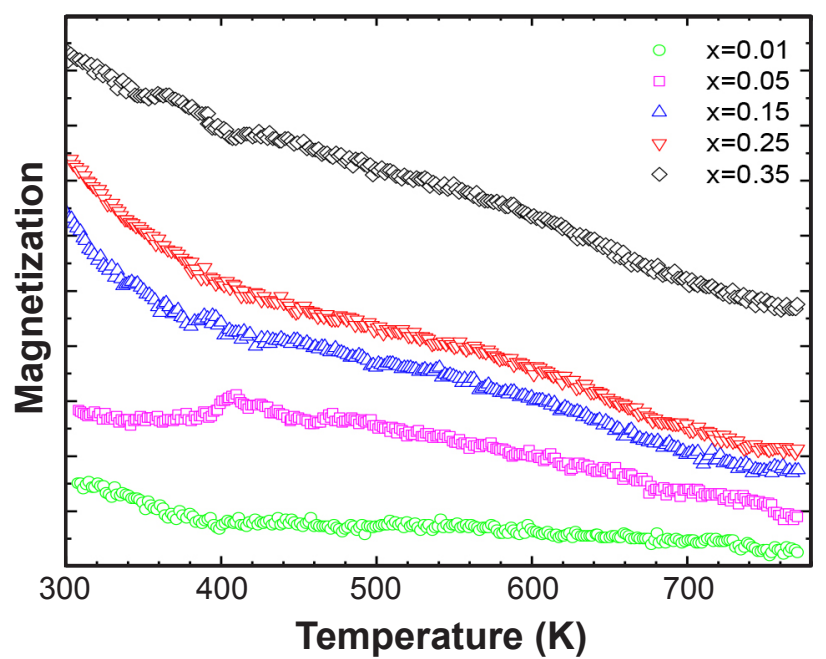

Figure 3: Magnetization temperature dependences measured for all $\mathrm{MgGa}_{2-\mathrm{x}} \mathrm{Fe}_{\mathrm{x}} \mathrm{O}_{4}$ samples.

[Figura 3: Dependência da magnetização com a temperatura medida para todas as amostras de $\left.\mathrm{MgGa}_{2-x} \mathrm{Fe}_{x} \mathrm{O}_{4} \cdot\right]$

is the expected behavior since the paramagnetic part of the $\mathrm{Ga}^{3+}$ ions was replaced by the ferromagnetic $\mathrm{Fe}^{3+}$ ions. This change on the cation distribution implies that the magnetic interactions between the magnetic ions on the octahedral sites are increased. Two slopes are observed indicating a two-step decay of the magnetization. All samples present a change in the decay slope of the magnetization close to 400 $\mathrm{K}$ and Curie temperature above $700 \mathrm{~K}$ that are listed in Table I, except for the sample with $\mathrm{x}=0.01$ that shows diamagnetic behavior, so it does not present Curie temperature [12]. Gilleo [13] indicated that the Curie temperature depends primarily upon the dominant $\left[\mathrm{Fe}^{3+}-\mathrm{O}^{2-}-\mathrm{Fe}^{3+}\right]$ linkages at tetrahedral and octahedral sites. The gallium ion, being diamagnetic, does not directly participate in the exchange interaction [14]. Probably the change in the decay slope is associated with the paramagnetic $\mathrm{Ga}^{3+}$ ions role and the $\mathrm{T}_{\mathrm{c}}$ is due to the $\mathrm{Fe}^{3+}$ ions role on the magnetization of the samples $[11,12]$. From the sample with $x=0.05$ it was observed a change in concavity of the curve with paramagnetic material characteristics.

Table I shows the results of the magnetic parameters,

Table I - Remanent magnetization $\left(\mathrm{M}_{\mathrm{R}}\right)$, coercivity $\left(\mathrm{H}_{\mathrm{C}}\right)$, saturation magnetization $\left(\mathrm{M}_{\mathrm{S}}\right)$, and Curie temperature $\left(\mathrm{T}_{\mathrm{c}}\right)$ for all $\mathrm{MgGa}_{2-\mathrm{x}} \mathrm{Fe}_{\mathrm{x}} \mathrm{O}_{4}$ samples.

[Tabela I - Magnetização remanente $\left(M_{R}\right)$, coercividade $\left(H_{C}\right)$, magnetização de saturação $\left(M_{S}\right)$ e temperatura de Curie (Tc) para todas as amostras de $\mathrm{MgGa}_{2-x} \mathrm{Fe}_{x} \mathrm{O}_{4}$.]

\begin{tabular}{ccccc}
\hline Sample & $\mathrm{M}_{\mathrm{R}}(\mathrm{emu} / \mathrm{g})$ & $\mathrm{H}_{\mathrm{C}}(\mathrm{G})$ & $\mathrm{M}_{\mathrm{S}}(\mathrm{emu} / \mathrm{g})$ & $\mathrm{T}_{\mathrm{c}}(\mathrm{K})$ \\
\hline $\mathrm{x}=0.01$ & 0.004 & ----- & 0.016 & ------- \\
$\mathrm{x}=0.05$ & 0.015 & 288.15 & 0.105 & 733.38 \\
$\mathrm{x}=0.15$ & 0.020 & 254.56 & 0.275 & 735.97 \\
$\mathrm{x}=0.25$ & 0.025 & 256.13 & 0.425 & 736.61 \\
$\mathrm{x}=0.35$ & 0.028 & 277.57 & 0.495 & 753.39 \\
\hline
\end{tabular}

remanent magnetization $\left(\mathrm{M}_{\mathrm{R}}\right)$, coercivity $\left(\mathrm{H}_{\mathrm{C}}\right)$, saturation magnetization $\left(\mathrm{M}_{\mathrm{S}}\right)$ and Curie temperature $\left(\mathrm{T}_{\mathrm{c}}\right)$, of all samples obtained from the hysteresis and the magnetizationtemperature curves. It can be seen that the values of saturation magnetization and remanence increased with increasing iron concentration. If the $\mathrm{Ga}^{3+}$ ions were supposed to enter only into the tetrahedral sites, even for small Ga concentration, the $\mathrm{Ga}^{3+}$ ions will cause $\mathrm{Fe}^{3+}$ ions to displace from tetrahedral to octahedral sites leading to an increase in magnetization which is observed in Table I [11]. The coercive field was unable to be determined for sample with $\mathrm{x}=0.01$, and from $\mathrm{x}=0.05$ to 0.15 it decreased with the concentration. From $\mathrm{x}=0.25$ is observed an increase in the coercive field with $\mathrm{x}$.

Samples with $\mathrm{x}$ up to 0.15 were highly insulating and, for this reason, electrical measurements were only possible to be obtained in a.c. Samples with $\mathrm{x}=0.25$ and $\mathrm{x}=0.35$ presented a semiconductor behavior which can be interpreted in the framework of the potential barrier between the crystallites model. Potential barrier between the crystallites model considers the electrical transport resistivity $(\rho)$ of thermally activated band conduction, expressed by Equation A $[9,10]$ :

$$
\rho=\left(\frac{2 \pi m^{*} k_{B} T}{L^{2} n}\right) \exp \left(\frac{E_{b}}{k_{B} T}\right)
$$

where, $e$ is the electron charge, $n$ is the electron concentration in neutral region of the crystallites, $L$ is the mean size of the crystallites, $k_{B}$ is the Boltzmann's constant, $\mathrm{m}^{*}$ is the effective mass of charge carriers, and $E_{b}$ is the energy barrier height between the crystallites, which can be expressed by Equation B $[9,10]$ :

$$
\mathrm{E}_{\mathrm{B}}=\left(\frac{\mathrm{L}^{2} \mathrm{e}^{2} \mathrm{~N}_{\mathrm{d}}}{8 \varepsilon}\right)
$$

where, $\varepsilon$ is the low frequency relative dielectric permittivity, and $N_{d}$ is the donor density. This effect can be verified by evaluation of the Debye screening length $\left(\mathrm{L}_{\mathrm{D}}\right)$ in comparison with the crystallites size $(L) . L_{D}$ is given by $[9,10]$ :

$$
\mathrm{L}_{\mathrm{D}}=\sqrt{\frac{\mathrm{k}_{\mathrm{B}} \mathrm{T} \varepsilon_{0} \varepsilon}{\mathrm{e}^{2} \mathrm{~N}_{\mathrm{d}}}}
$$

where, $\varepsilon_{0}$ is the vacuum dielectric constant. If $\mathrm{L}_{\mathrm{D}}<\mathrm{L} / 2$, charge carriers remain confined to the grains and potential barriers between the crystallites region due to interface trap states. If, however, $\mathrm{L}_{\mathrm{D}}>\mathrm{L} / 2$, the barrier limited conductivity mechanism dominates and the electrons are transported with negligible grain boundary scattering $[9,10]$. It was examined the plots of $\ln \left(\rho \mathrm{T}^{-1 / 2}\right)$ vs. $10^{3} / \mathrm{T}$ for all samples. The large linear temperature region of the plots observed in Fig. 4 reveals that, for the studied domain of the temperature, is an evidence that the crystallites scattering of the charge carriers dominates in the investigated samples [9].

In order to complete verification of the potential barrier 


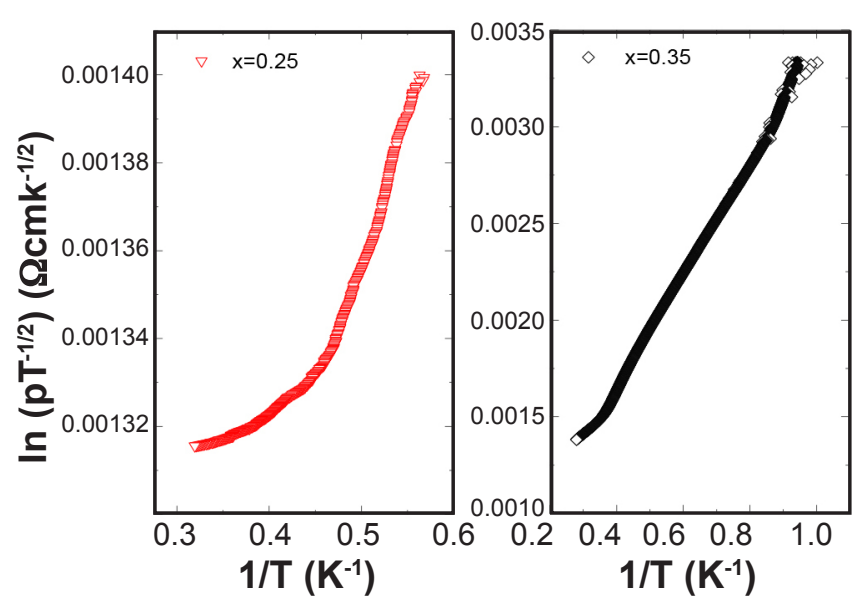

Figure 4: Inverse temperature dependence of the resistivity $\left[\ln \left(\rho T^{-1 / 2}\right)\right]$.

[Figura 4: Dependência da resistividade $\left[\ln \left(\rho T^{1 / 2}\right)\right]$ com o inverso da temperatura.]

between the crystallites model, it is necessary to measure the dielectric permittivity for all samples. The dielectric permittivity of all samples have been calculated considering a.c. capacitance measurements in the frequency range of 1 $\mathrm{Hz}$ to $40 \mathrm{MHz}$ and Equation D. In this equation, $C$ is the capacitance of the pellet, $d$ is the thickness of the pellet, $A$ is the cross-sectional area of the flat surface of the pellet, and $\varepsilon_{0}$ is the permittivity constant of free space.

$$
\varepsilon=\frac{\mathrm{Cd}}{\varepsilon_{0} \mathrm{~A}}
$$

The frequency dependence of dielectric permittivity of all samples is shown in Fig. 5. It is observed that the dielectric permittivity of all samples decreases with increasing frequency. The dielectric permittivity of these samples may be related to the space-charge polarization since higher conductivity grains are separated by insulating grain boundaries which produces localized accumulation of charge under the influence of an alternated electric field [15]. According to Maxwell and Wagner two-layer model, spacecharge polarization is due to the inhomogeneous dielectric structure of the material $[15,16]$. A similar variation of the dielectric constant with frequency was observed in the case of $\mathrm{ZnFe}_{2} \mathrm{O}, \mathrm{MnFe}_{2} \mathrm{O}_{4}[17], \mathrm{Zn}_{\mathrm{x}} \mathrm{Cu}_{1-\mathrm{x}} \mathrm{Fe}_{2} \mathrm{O}_{4}$ and $\mathrm{Mn}_{\mathrm{x}} \mathrm{Cu}_{1-\mathrm{x}} \mathrm{Fe}_{2} \mathrm{O}_{4}$ [18] ferrite systems. Koops [19] proposed that the effect of grain boundaries is predominant at low frequencies; the thinner the grain boundary, the value of dielectric constant is higher. It is seen that the value of the dielectric constant is very high at low frequencies and decreases with increasing frequency, and then at higher frequency they become almost constant. The decrease in dielectric constant value with increasing frequency is attributed to the fact that the electron exchange between $\mathrm{Fe}^{2+}$ and $\mathrm{Fe}^{3+}$ ions cannot follow the change of the external applied field beyond certain frequency $[16,20]$. At low frequencies, grain boundaries are more effective than grain electrical conduction. The higher

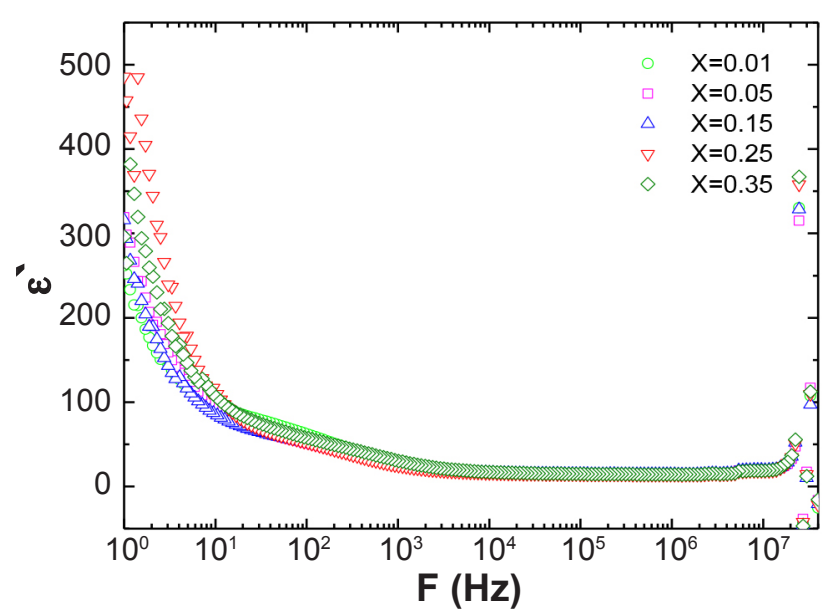

Figure 5: Frequency dependence of dielectric permittivity for all samples.

[Figura 5: Dependência da permissividade dielétrica com a frequência para todas as amostras.]

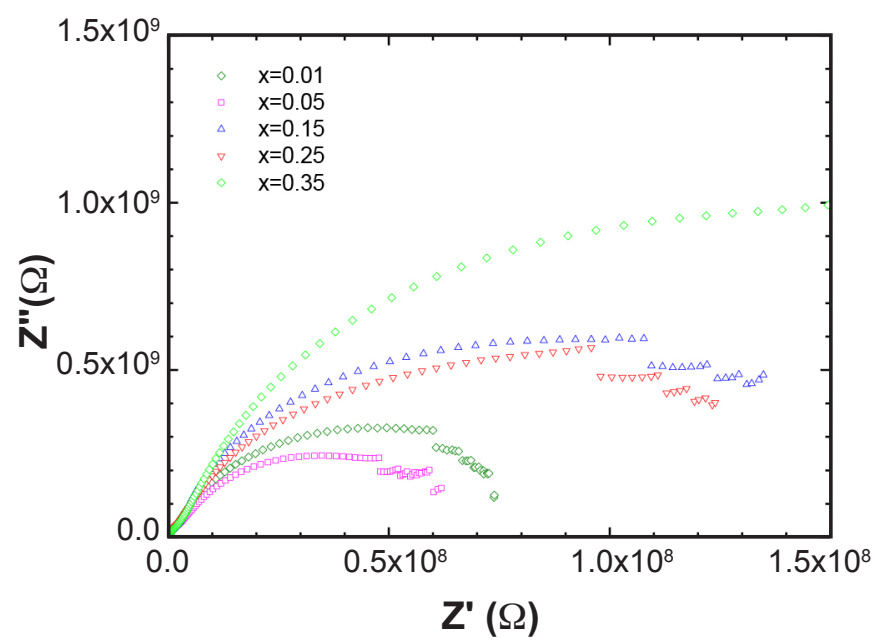

Figure 6: Complex impedance spectra for all samples.

[Figura 6: Espectro de impedância complexa para todas as amostras.]

value of dielectric constant at low frequency is due to voids, dislocations and other defects $[16,20]$. In the high frequency range, which corresponds to low resistivity due to the grains, a small energy is needed for electron transfer between $\mathrm{Fe}^{2+}$ and $\mathrm{Fe}^{3+}$ ions in grains and accompanied by a small eddy current and hence a decrease in the energy loss in all samples $[16,20]$.

The complex-plane impedance spectrum of samples measured at room temperature is shown in Fig. 6. The impedance spectroscopy is widely used to characterize the electrical properties of materials and interfaces present in these materials. The impedance measurements data gives both resistive (real) and reactive (imaginary) components for a material. To separate the grain and grain boundary contributions of the samples, complex impedance plane plots have been drawn in the frequency range at room temperature. It is clear from Fig. 6 that all the samples show 
Table II - Values of barrier height $\left(\mathrm{E}_{\mathrm{B}}\right)$, dielectric permittivity $(\varepsilon)$, donor concentration $\left(\mathrm{N}_{\mathrm{d}}\right)$, average crystallite size $(\mathrm{L})$, and Debye screening length $\left(\mathrm{L}_{\mathrm{D}}\right)$.

[Tabela II - Valores de altura da barreira $\left(E_{B}\right)$, permissividade dieléctrica $(\varepsilon)$, concentração dos doadores $\left(N_{d}\right)$, tamanho médio de cristalito $(L)$ e comprimento de Debye $\left(L_{D}\right)$.]

\begin{tabular}{cccccc}
\hline Sample & $\mathrm{E}_{\mathrm{b}}(\mathrm{meV})$ & $\varepsilon$ & $\mathrm{N}_{\mathrm{d}}\left(\mathrm{m}^{-3}\right)$ & $\mathrm{L}_{\mathrm{D}}(\mathrm{nm})$ & $\mathrm{L}(\mathrm{nm})$ \\
\hline 0.25 & 15.53 & 186.81 & $6.31 \times 10^{22}$ & 28.90 & 142.5 \\
0.35 & 19.63 & 23.67 & $1.01 \times 10^{22}$ & 23.43 & 142.4 \\
\hline
\end{tabular}

one incomplete arc due to grain boundary conduction. The incomplete circular arc in low frequency region shows that grain boundary resistance is out of measurement scale or presence of some additional relaxation phenomena which occur outside the measured frequency range.

Now, considering the static permittivity $\varepsilon$ as the lowest frequency mean value at the flattest part of the results of Fig. 5, it can be proceeded to the potential barrier between the crystallites model. From the curves of Fig. 4, the values of $\mathrm{E}_{\mathrm{b}}$ were calculated from the slopes of the linear dependences and their values are shown in Table II. Then, it was determined the concentration of donors $\left(N_{d}\right)$ values using the Equation $\mathrm{B}$. Identifying the $\mathrm{N}_{\mathrm{D}}$ values, the values of the Debye length $\left(L_{D}\right)$ was calculated using Equation $\mathrm{C}$, which values are given in Table II. Applying the potential barrier between the crystallites model in the samples with $\mathrm{x}=0.25$ and 0.35 it was found that the barriers defined the conduction mechanism since for both samples $L_{D}<L / 2$. The $\mathrm{E}_{\mathrm{b}}$ value for both samples was, however, small, which agrees with the small difference between $L / 2$ and $L_{D}$, meaning that further increase in $\mathrm{x}$ would lead to a sample with no barrier between the crystallites.

\section{CONCLUSIONS}

The XRD patterns of the samples showed the same diffraction peaks typical of basic structure, as the $\mathrm{MgGa}_{2} \mathrm{O}_{4}$ - $\mathrm{MgFe}_{2} \mathrm{O}_{4}$ and confirmed the formation of a single phase cubic spinel structure. Through the hysteresis loops, the samples showed characteristics of a soft magnetic material. From the data, it is observed that the saturation magnetization and remanence of the samples increase with increasing iron concentration. The coercive field decreases to the concentration with $\mathrm{x}=0.15$, and from $\mathrm{x}=0.25$ is observed an increase in the coercive field. The samples studied have ferromagnetic ordering below Curie temperature $\left(\mathrm{T}_{c}\right)$ while the spontaneous magnetization increases with increasing the $\mathrm{Fe}^{3+}$ concentration $(\mathrm{x})$. Magnetization decreases with the increase in temperature, as would be expected from a system with ferromagnetic coupling below $\mathrm{T}_{\mathrm{c}}$. The resistivity for the samples with $\mathrm{x}=0.25$ and 0.35 decreases with the increase in temperature showing a semiconductor behavior, and the samples with $\mathrm{x}=0.01$ to 0.25 showed the behavior of an insulating material. Applying the potential barrier between the crystallites model in the samples with $\mathrm{x}=0.25$ and 0.35 , it was found that energy barriers between the crystallites limits the conduction of the samples with energies lower than $20 \mathrm{meV}$.

\section{ACKNOWLEDGMENTS}

The authors are thankful to CNPq, CAPES and FAPEMIG for the financing support of this research work.

\section{REFERENCES}

[1] S. Wu, J. Xue, R. Wang, J. Li, J. Alloys Compd. 585, 5 (2014) 542-548.

[2] D.R. Askeland, P.P. Fulay, W.J. Wright, The Science and Engineering of Materials, Publisher CL Engineering (2010). [3] Q.M. Wei, J.B. Li, Y.J. Chen, Y.S. Han, Mater. Charac. 47, 3-4 (2001) 247-252.

[4] L.P. Sosman, R.J.M. da Fonseca, A. Dias Tavares Jr., T. Abritta. Cerâmica 52, 322 (2006) 200-204.

[5] G.K.B. Costa, L.P. Sosman, A. López, N. Cella, R.B. Barthem, J. Alloys Compd. 534, 5 (2012) 110-114.

[6] A.C.F.M. Costa, M.R. Morelli, R.H.G.A. Kiminami, Cerâmica 49, 311 (2003) 168-173.

[7] O. Mirzaee, A. Shafyeia, M.A. Golozara, H. Shokrollahib, J. Alloys Compd. 461, 1-2 (2008) 312-315.

[8] O. Mirzaee, J. King Saud University - Eng. Sci. 26, 2 (2013) 1-7.

[9] D. Mardare, N. Iftimie, M. Crişan, M. Răileanu, A. Yildiz, T. Coman, K. Pomoni, A. Vomvas, J. Non-Cryst. Solids 357, 7 (2011) 1774-1779.

[10] A. Yildiz, N. Serin, M. Kasap, T. Serin, D. Mardare, J. Alloys Compd. 493, 1-2 (2010) 227-232.

[11] A.A. Sattar, Egypt. J. Sol. 27, 1 (2004) 99-110.

[12] A. Franco, Jr. M. S. Silva, J. Appl. Phys. 107, 07 B505

(2011) 109-11.

[13] M.A. Gilleo, Phys. Chem. Solids 13 (1960) 33.

[14] M. Kaiser, S.S. Ata-Allah, Phys. Status Solidi B 242, 15 (2005) 3138-3148.

[15] H. Farooq, M.R. Ahmad, Y. Jamil, A. Hafeez, Z. Mahmood, T. Mahmood, J. Basic Appl. Sci. 8, 2 (2012) 597 601.

[16] R. Sridhar, D. Ravinder, K.V. Kumar, Int. J. Eng. Res. Appl. 3, 5 (2013) 2021-2024.

[17] K. Iwauchi, Japanese J. Appl. Phys. 10, 11 (1971) 15201528.

[18] N. Rezlescu, E. Rezlescu, Phys. Status Solidi A 23, 2 (1974) 575-582.

[19] C.G. Koops, Phys. Rev. 83, 121 (1951) 121-124.

[20] S.S. Karande, B.R. Karche, Int. J. Emerging Techn. Adv. Eng. 4, 10 (2014) 602-608.

(Rec. 02/11/2015, Rev. 29/01/2016, 04/03/2016, Ac. $09 / 05 / 2016)$ 